\title{
The National Institutes of Health chronic prostatitis symptom index
}

\section{（NIH-CPSI，日本語版・岡山大学案）の有用性と同案を用いた 慢性非細菌性前立腺炎に対するセルニチンポーレンエキスの臨床評価}

岡山大学大学院医歯学総合研究科泌尿器病態学 (主任: 公文裕巳教授)

$\begin{array}{llll}\text { 門田 } & \text { 晃一 } & \text { 津川 } & \text { 昌也 二八宮祐子 } \\ \text { 安東 } & \text { 栄一 } & \text { 公文 } & \text { 裕巳 }\end{array}$

A JAPANESE VERSION OF THE NATIONAL INSTITUTES OF HEALTH CHRONIC PROSTATITIS SYMPTOM INDEX (NIH-CPSI, OKAYAMA VERSION)

AND THE CLINICAL EVALUATION OF CERNITIN POLLEN

EXTRACT FOR CHRONIC NON-BACTERIAL PROSTATITIS

\author{
Koichi Monden, Masaya Tsugawa, Yuko Ninomiya, \\ Eiichi Ando and Hiromi Kumon \\ Department of Urology, Okayama University Graduate School of Medicine \\ and Dentistry, Okayama, Japan
}

(Purpose) The chronic prostatitis syndromes are common disorders in urologic practice and present various clinical symptoms. The development of a chronic prostatitis symptom index appropriate for judgment of therapeutic effects is awaited since the pathophysiology and appropriate treatment are not well defined so far. We developed a Japanese version of the National Institutes of Health Chronic Prostatitis Symptoms Index (NIH-CPSI, Okayama version), and examined its usefulness. In addition, we evaluated clinical effects of Cernilton ${ }^{\mathbb{k}}$ for chronic nonbacterial prostatitis using this symptom index.

(Subjects and methods) A total of 87 patients including 34 patients with NIH chronic prostatitis category III, 35 patients with BPH and 18 patients for control group who visited the Department of Urology at Okayama University Medical School filled in the questionnaire of our Japanese version of the NIH-CPSI to compare the NIH-CPSI scores among three groups. Twenty-four patients with NIH chronic prostatitis category III (IIIa 16, IIIb 8) were treated with Cernilton ${ }^{\text {k }}$ and the NIH-CPSI scores were examined before and after its administration.

(Results) The pain/discomfort domain score was 9.79 (mean) in the chronic prostatitis group, 1.66 in the $\mathrm{BPH}$ group and 0.39 in the control group ; that of the urinary symptom domain was 3.82 , 3.29 and 0.72 , respectively ; and that of the quality of life (QOL) was $8.21,4.17$ and 1.39 , respectively. The pain/discomfort domain score was significantly higher in the chronic prostatitis group than in the other groups; the QOL domain score was higher in the order of the chronic prostatitis group, the $\mathrm{BPH}$ group and the control group. In the chronic prostatitis group, there was a significant, positive correlation between the pain/discomfort domain score and that of the QOL, and between the urinary symptom domain score and that of the QOL. These results suggested the usefulness of our Japanese version of the NIH-CPSI as a parameter of the severity of chronic prostatitis. Examination of changes in the NIH-CPSI scores revealed that scores of the items in all domains were significantly lower 4 to 6 weeks after the start of administration of Cernilton ${ }^{k}$ than those obtained before the drug administra- 
tion in patients with chronic prostatitis.

(Conclusions) A Japanese version of NIH-CPSI (Okayama version) accurately reflects clinical symptoms and the QOL in patients with chronic prostatitis. It seemed to be a useful and appropriate system for scoring symptoms of chronic prostatitis, indicating further studies on translation, adaptation and validation of the NIH-CPSI in Japan.

Key words : Chronic prostatitis, NIH-CPSI, Cernilton ${ }^{\text {ik. }}$

要旨：(目的) NIH-CPSI の日本語版 (岡山大学案)を作成し，その有用性について検討した。この symptom index を用いて慢性非細菌性前立腺炎に対するセルニルトン"の臨床効果を評価した。

(対象・方法) 対象は慢性前立腺炎群 34 例, BPH 群 35 例, コントロール群 18 例とし, 我々が作成し た NIH-CPSI・日本語版（岡山大学案）のスコアを比較検討した。慢性非細菌性前立腺炎 24 例にセルニ ルトントを投与し，投与開始前後の NIH-CPSI スコアを比較検討した.

(結果) 各疾患群のスコアは, 痛み・不快感 [慢性前立腺炎群：9.79 (平均値), BPH 群：1.66, コント ロール群 : 0.39], 排尿刺激症状 $[3.82,3.29,0.72]$, QOL $[8.21,4.17,1.39]$ であった。痛み・不快感に関す る領域は慢性前立腺炎群が他群と比べ有意に高く, QOL に関する領域は, 慢性前立腺炎群, BPH 群, コ ントロール群の順に高い結果であった。 慢性前立腺炎群では痛み・不快感, 排尿刺激症状と QOL のスコ アに統計学的にそれぞれ順相関が認められ前立腺炎の重症度の指標として有用であることが示唆され た. セルニルトン・投与後の各領域のスコアは投与前と比較して有意に低下していた。

（結論） NIH-CPSI ・日本語版（岡山大学案）は，慢性前立腺炎の臨床症状および QOL を的確に反映し ており, 有用であった，今後さらに，翻訳の質，妥当性および信頼性など検討するに值する症状スコア と考えられた。

キーワード：慢性前立腺炎, 症状スコア, セルニルトン'i

\section{緒言}

前立腺炎は成人男性に発症する性器疾患の一つで, 比較的頻度の高い泌尿器科疾患である. 従来, その病 型は急性細菌性, 慢性細菌性, 慢性非細菌性ならびに 前立腺痛 (prostatodynia) に分類されてきたが")，1995 年には NIH から新しい病型分類が提唱されだ!。それ によると I 型が急性細菌性, II 型が慢性細菌性となり, 慢性非細菌性と前立腺痛は III 型（慢性非細菌性， Chronic pelvic pain syndrome）として一括され，それ ぞれ IIIA（炎症性），IIIB（非炎症性）に分類された. また新にIV 型として無症候性・炎症性前立腺炎が加 わっている.

この III 型前立腺炎は, 現在においてもその病因が 解明されておらず, 各種治療に抵抗性を示し難治性で あることから臨床的に課題の多い疾患である。また， III 型前立腺炎は多彩な臨床症状を呈する病態群であ り, その病因の究明, 治療効果の判定のために適切な 症状スコアの作成が望まれている。1999 年には NIH より慢性前立腺炎での重症度と治療効果判定のための the National Institutes of Health chronic prostatitis symptom index (NIH-CPSI) が公表され ${ }^{3 \prime}$ ，北米を中心
にこの NIH-CPSI を用いた研究がいくつか報告されて いる(1-8). 今回, 我々はこの NIH-CPSI の日本語版 (岡 山大学案）を作成し，その有用性について検討すると ともに,この symptom index を用いて慢性非細菌性前 立腺炎/Chronic pelvic pain syndrome（IIIA 型および IIIB 型前立腺炎) に対するセルニチンポーレンエキス (セルニルトン ${ }^{k}$, 扶桑薬品) の臨床効果を評価したの で報告する.

\section{対象・方法}

2000 年 3 月から 2001 年 2 月の期間に岡山大学泌尿 器科外来を受診した慢性非細菌性前立腺炎患者 34 例 (IIIA 型 : 24 例, IIIB 型：10 例), 前立腺肥大症 (BPH) 患者 35 例，コントロール患者 18 例を対象とした。患 者の年齢は, 慢性非細菌性前立腺炎患者では 20〜 76 歳(平均士標準偏差： $45.0 \pm 16.5$ 歳), BPH 患者では 51 ～85 歳 (69.3 06.3 歳)，コントロール患者では 33〜82 歳 $(53.1 \pm 13.9$ 歳)であった。前立腺炎の診断は尿路感 染症臨床試験ガイドライン を产考に, 臨床症状と前立 腺压出液所見（EPS）より行ったＥPS 中の細菌数が $10^{3} \mathrm{CFU} / \mathrm{ml}$ 末満 (ただしグラム陽性球菌では $10^{\mathrm{A}} \mathrm{CFU} /$ $\mathrm{ml}$ 未満) かつ白血球数が $10 \mathrm{WBCs} / \mathrm{HPF}$ 以上を IIIA 
型前立腺炎, 白血球数が $10 \mathrm{WBCs} / \mathrm{HPF}$ 未満を IIIB 型前立腺炎と診断した。コントロール患者は疼痛，不 快感, 排尿症状以外の症状で当科外来を受診した男性 患者とした。コントロール患者の疾患の内訳は高尿酸 血症 4 例, PSA 高值の精査 3 例, 尿路結石 3 例, 腎囊 胞 2 例, 顕微鏡的血尿 2 例, その他 4 例であった. NIHCPSI - 日本語版 (岡山大学案) (図 1) の作成手順は, まず 2 名の泌尿器科専門医（著者のうち 2 名）が NIHCPSI 原本を和訳し, その和訳の内容が原本と比較して 相違, 矛盾のないことを 2 名の日本在住米国人（英会 話講師と中学校英語講師) に確認した. NIH-CPSI の質 問は大きく 3 領域に分類され，それぞれ痛み・不快感 に関する 4 項目（項目 1〜4, 合計スコア：0２1点),
排尿刺激症状に関する 2 項目（項目 5 6, 合計スコ ア：0１0点), QOL に関する 3 項目 (項目 7〜9, 合計 スコア: 0 12 点)の合計 9 項目から構成されている. 今回, 我々が作成した NIH-CPSI ・日本語版 (岡山大学 案) に加え the international prostate symptom score (IPSS)のアンケートを, 対象となった患者自身に記載 していただき各疾患群でスコアを比較検討した.また， 慢性非細菌性前立腺炎患者群では痛み・不快感ならび に排尿刺激症状に関するスコアとQOL に関するスコ アの相関関係についても検討した。

慢性非細菌性前立腺炎患者 34 例のうちセルニルト ン ${ }^{R}$ (1 回 2 錠，1 日 3 回経口投与）を投与した 24 例 (IIIA 型：16 例, IIIB 型： 8 例)を対象として, 投与開

図 1 NIH CHRONIC PROSTATITIS SYMPTOM INDEX (NIH-CPSI) - 日本語版（岡山大学案）

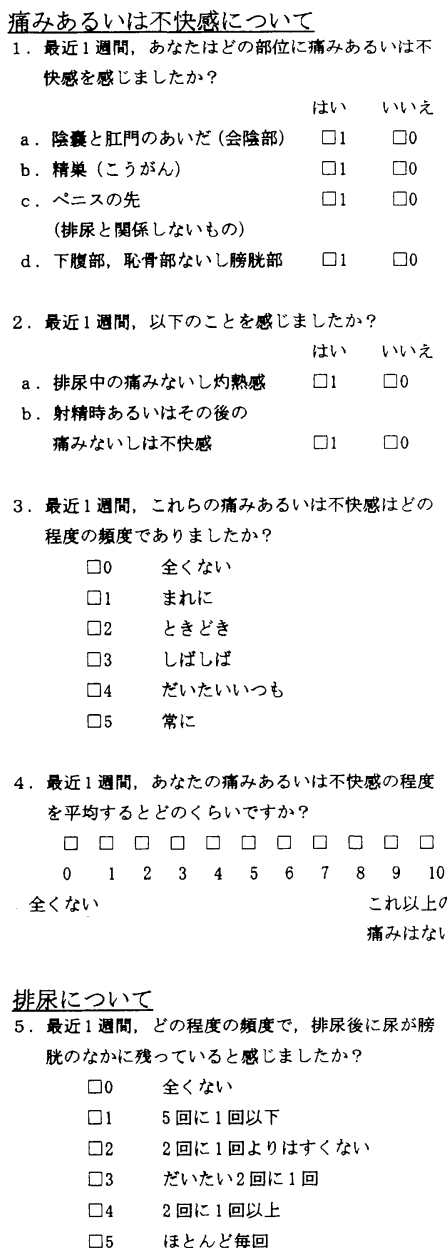

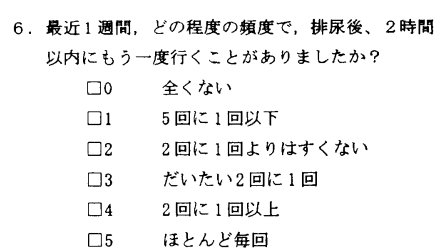

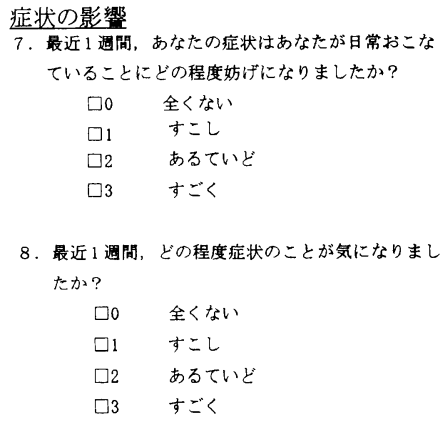

Quality of life 9. 最近 1 週間の状態が, 今後も綨くとしたらと゚う感じ ますか。

$\square 0 \quad$ 非常に满足

$\square 1$ 满足

$\square 2$ ほほ满足

$\square 3$ 満足、不满どちらでもない

$\square 4$ 队р不満

$\square 5$ 不满

$\square 6$ 全く我僈できない
各領域でのスコアー化

・痛み: 項目 $1 \mathrm{a}, 1 \mathrm{~b}, 1 \mathrm{c}, 1 \mathrm{~d}, 2 \mathrm{a}, 2 \mathrm{~b}, 3$ および4の総計 点

- 排尿症状: 項目 5 と 6 の総計

-QOL : 項目 7,8 および 9 の総計 
始前と投与開始後 4 6 週目の NIH-CPSI - 日本語版 (岡山大学案) のスコアを比較し，七ルニルトンの臨 床効果を評価した。 セルニルトン ${ }^{\mathbb{B}}$ の投与期間は 4 36 週間 (平均 11.8 週間，中央值 10 週間)であった。なお, セルニルトン"投与開始前 1 力月以内に慢性前立腺炎 に対して何らかの治療が施行された症例は除外した.

有意差の検定には Wilcoxon signed rank test を用 い，相関係数の計算には，正規性を仮定しないノンパ ラメトリックなSpearmanの相関係数を用いた。

\section{結果}

図 2 に各疾患群における NIH-CPSI の成績を示す. 痛み・不快感に関する領域では，慢性前立腺炎群のス コアはBPH 群およびコントロール群に比べ有意に高 值であった. BPH 群とコントロール群では有意差を認 めなかった，排尿刺激症状に関する領域では，慢性前 立腺炎群と BPH 群はコントロール群に比べ有意に高 值であった．慢性前立腺炎群と BPH 群では有意差を 認めなかった，QOLに関する領域では，慢性前立腺炎 群，BPH 群，コントロール群の順に高值を示し，各疾 患群間でそれぞれ有意差を認めた。なお，IIIA 型と IIIB 型前立腺炎では, 各領域のスコアはほほ同様の傾 向を示し，両者間で有意差を認めなかった. NIH-CPSI の公表時に報告された北米における多数例による成 績3) と我々の施設における成績を比較すると, 各疾患群 でほぼ同様の傾向を示し各領域のスコアの平均值も類 似していた（表 1).

慢性前立腺炎群における疼痛・不快感と QOL スコ ア間の相関係数は $0.662(\mathrm{p}<0.0001)$ ，排尿刺激症状と

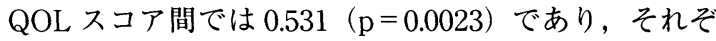
れ統計学的に順相関が認められた（図 3 ).

IPSS の成績を図 4 に示す. IPSS は，BPH 群，慢性 前立腺炎群，コントロール群の順に高值を示し，各疾 患群の間でそれぞれ有意差を認めた．IPSSに関する QOL スコア（QOL-IPSS）は，慢性前立腺炎群と BPH 群はコントロール群に比べ有意に高值であり，慢性前 立腺炎群と $\mathrm{BPH}$ 群の間では有意差を認めなかった。

III 型前立腺炎に扔けるセルニルトン"投与開始前後 の NIH-CPSI のスコアの推移を検討すると，七ルニル トン“投与開始前と比較して投与開始 $4 \sim 6$ 週後のスコ アはすべての領域で統計学上有意に低下していた（図 5)。また，項目 9 の満足度に関する質問では，やや不 満，不満，全く我慢できないとした患者は，投与開始 前では $91.7 \%(22 / 24)$ であったが, 投与開始後には 33.3 \% (8/24) に減少した。ほほ満足，満足，非常に満足 とした患者は, 投与開始前には 1 例も認めなかったが, 投与開始後には 50\%（12/24）に増加した（図 6)。各 領域のスコアの総合計スコア $(0 \sim 43$ 点 $)$ が投与後に投 与前の $50 \%$ 以下に低下した症例は $62.5 \%(15 / 24)$, 項 目 9 の满足度が投与前より 2 段階以下に低下した症例 は 62.5\%（15/24）であり，どちらかいずれかを満足し た症例は 66.7\%(16/24)であった. なお, IIIA 型と IIIB 型前立腺炎における投与前後のスコアの推移はほほ同 様の傾向を示し, 2 つの病態間でセルニルトン ${ }^{\mathrm{N}}$ の有効 性に差を認めなかった。

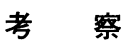

NIH-CPSI は NIH の強力なサポートにより，北米の

図 23 疾患群における NIH-CPSI の成績
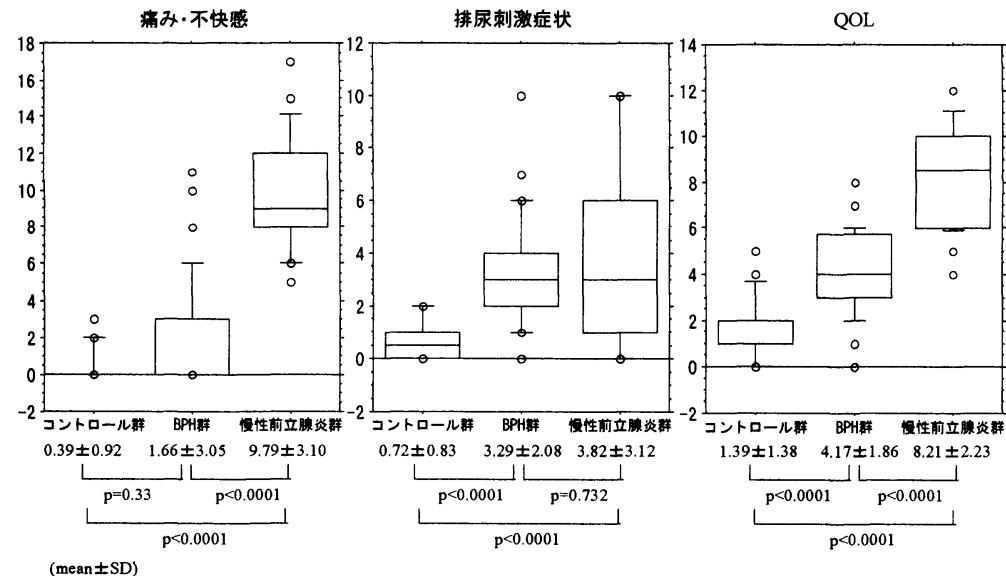

(mean $\pm S D$ ) 
表 1 岡山大学泌尿器科泌尿器科と NIH-CPSI 公表時に報告された北米にお ける NIH-CPSI の成績 ${ }^{3)}$

\begin{tabular}{l|c|c}
\hline 疾患名 (スコアレンジ) & 岡山大学泌尿器科 & 北米 (NIH-CPSI 公表時) \\
\hline 慢性前立腺炎 & & \\
痛み・不快感 $(0-21)$ & $9.8 \pm 3.1$ & $8.7 \pm 5.7$ \\
排尿症状 $(0-10)$ & $3.8 \pm 3.1$ & $4.1 \pm 3.1$ \\
QOL $(0-21)$ & $8.2 \pm 2.2$ & $6.7 \pm 3.6$ \\
BPH & & \\
痛み・不快感 & $1.7 \pm 3.0$ & $1.7 \pm 2.7$ \\
排尿症状 & $3.3 \pm 2.1$ & $3.6 \pm 2.5$ \\
QOL & $4.2 \pm 1.9$ & $2.2 \pm 2.6$ \\
コントロール & & \\
痛み・不快感 & $0.4 \pm 0.9$ & $0.4 \pm 1.3$ \\
排尿症状 & $0.7 \pm 0.8$ & $1.0 \pm 1.3$ \\
QOL & $1.4 \pm 1.4$ & $0.6 \pm 1.5$ \\
\hline
\end{tabular}

(平均士標準偏差)

図 3 III 型前立腺炎における痛み・不快感および排尿刺激症状と QOL スコアの関係

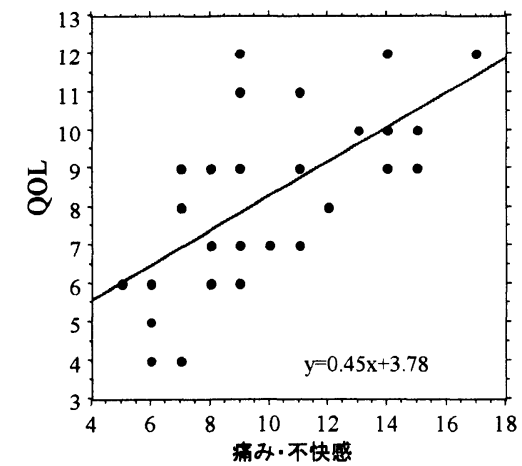

有み・不快感

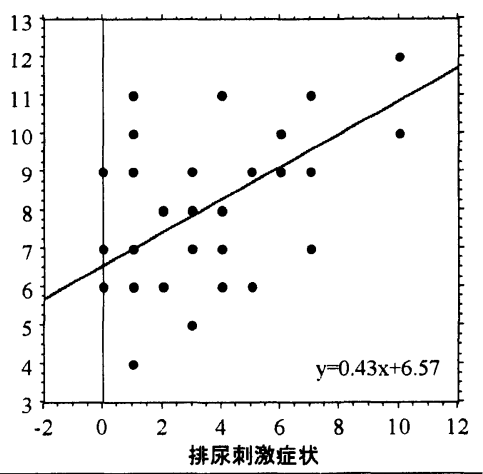

0.531

0.0023
多施設共同で作成された慢性前立腺炎に対する新しい 症状スコアである. NIH-CPSI では, 前立腺炎様症状や QOL に関する多数の質問項目の中から, Cognitive test, Validation test を経て健常者や BPH 患者との鑑 別に有用とされ，さらに test-retest reliability の高 かった 9 項目が最終的に採択されている ${ }^{31}$.すでに北 米を中心とした多数の施設では，この NIH-CPSI を前 立腺火症状スコアとして採用し，臨床試験の効果判 定 $^{455}$ や慢性前立腺炎の疫学調查 ${ }^{6 / 7)}$ を報告しいている. 一方, 本邦では統一された前立腺炎症状スコアはなく, 慢性前立腺炎の臨床試験に関する報告では治療効果の 判定方法も様々であり，それぞれの結果を比較検討す
ることは困難である。したがって，本邦においても慢 性前立腺炎症状スコアの確立が必要であり，今後の国 際的 Bridging studyも視野に入れると NIH-CPSI を 活用するのが妥当と考えられる.

今回, 我々の施設でこの NIH-CPSI の日本語版(岡山 大学案)を作成し，慢性前立腺炎，BPH ならびにコン トロール症例の 3 疾患群を対象にアンケートを実施し 比較検討した。 その結果, 慢性前立腺炎群では痛み・ 不快感に関するスコアは他の 2 疾患群に比べ有意に高 值を示し, 痛み・不快感が慢性前立腺炎の主症状であ ることが再確認された。 QOL に関するスコアも同様に 慢性前立腺炎群が他の 2 疾患群に比べ有意に高值を示 
し，慢性前立腺炎群の QOL が高度に障害されている ことがうかがわれた，米国では慢性前立腺炎患者の QOL にあたえる影響は心筋梗塞，不安定狭心症，活動 性のクローン病とほほ同程度と報告されているが101, 本邦においても慢性前立腺炎患者の QOL は，米国と 比べ大差はないものと思われた。また，慢性前立腺炎 群の排尿刺激症状に関するスコアは BPH 群とほぼ同 等であり，慢性前立腺炎患者は BPH 患者と同程度の 排尿刺激症状を自覚していることが判明した。我々の 成績と米国を中心とした北米での成績”を比較すると 3 群間における各領域のスコアは極めて類似してい た. 以上の成績からも慢性前立腺炎患者の臨床症状お よび生活に与える影響は日本と米国で同程度であるこ

図 43 疾患群における IPSS の成績
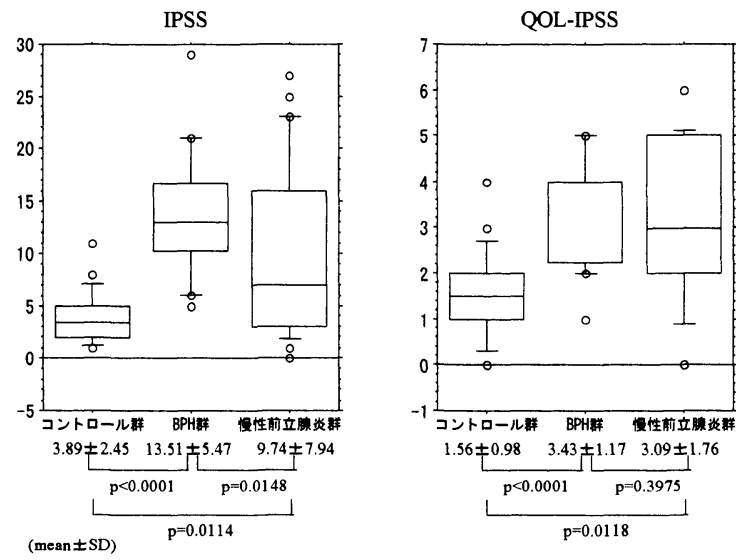

とが示唆されるとともに, NIH-CPSI ・ 日本語版（岡山 大学案）の内容はオリジナル版と比較して臨床症状の 把握という観点からも大きな差異はないものと考え る.さらに, III 型前立腺炎では, QOL スコアと痛み・ 不快感㧍よび排尿刺激症状に関するスコアは，それぞ れ統計学上順相関を認め, 特に痛み・不快感はより強 い相関を示したことから，NIH-CPSI の項目にある臨 床症状は的確にQOL に反映しており，慢性前立腺炎 の重症度の指標として有用であることが示唆された。

しかし, NIH-CPSI ・日本語版 (岡山大学案) では, 今後解決すべき課題も残されている. NIH-CPSI の日 本語版を確立するためには, QOL 調査票のひとつであ るSF-36において, International Quality of Life Assessment Project（IQOLA）が設けたガイドライン に 沿って日本語版の開発 ${ }^{121131}$ がなされたように国際的基 準に合致した翻訳の質，尺度の妥当性および信頼性に 関する解析が必須であろう. 現在, 国島ら ${ }^{14}$ の札幌医科 大学泌尿器科を中心としたグループも NIH-CPSI・日 本語版を作成し，これらの解析を行なっている. 今回, 岡山大学案として作成したNIH-CPSI ・ 日本語版も, その有用性が示唆されたことから, 尺度の妥当性抢よ び信頼性など更に詳細な検討を進めるに值するものと 考えられた. 泌尿器科領域では, 国際勃起機能スコア の日本語版が作成され，その妥当性については詳細に 検討がなされている ${ }^{151}$. しかし，そのスコアは，一般に 使用される段階で日本語訳の内容がわかりにくいとの 批判が多く，現在再検討がなされている ${ }^{161}$. NIH-CPSI ・日本語版の開発においても注意を要する点であり, 日本の患者に理解し易い症状スコアの作成を目指す必

図 5 III 型前立腺炎におけるセルニルトン投与前後の NIH-CPSI の推移
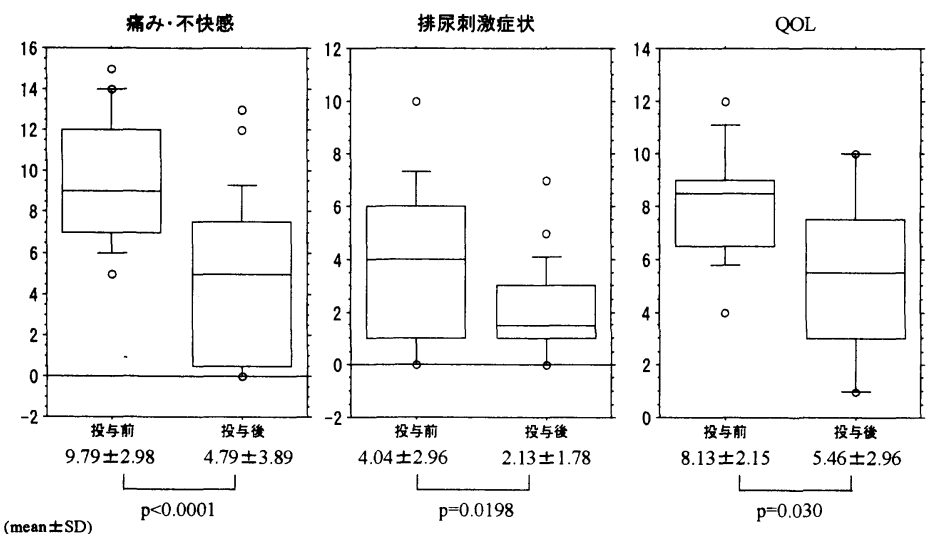
図 6 III 型前立腺炎におけるセルニルトン投与前後 の満足度（NIH-CPSI 項目 9）の推移

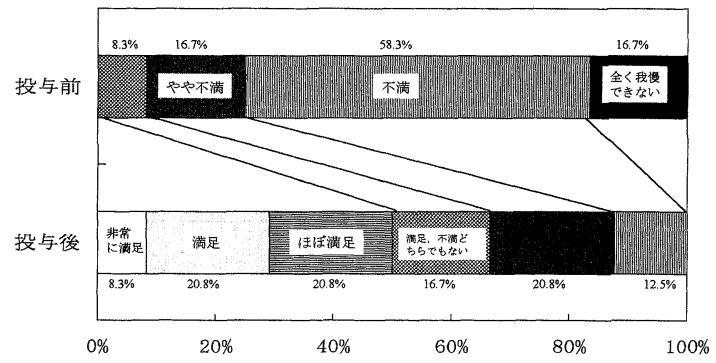

要があるまた，日本の前立腺炎患者の症状をより的 確に反映すると考えられる質問項目についても検討を 加え, その結果によっては新たな尺度の作成も視野に 入れる必要があろう。今後, 国内でも多施設による慢 性前立腺炎の臨床研究が企画されることが予想され, 前立腺炎の症状スコアの作成は重要課題である.今後, NIH-CPSI を中心に検討を進め, 必要であれば日本の 前立腺炎患者に適した独自の症状スコアの確立も考慮 すべきであろう。

慢性非細菌性前立腺炎は多彩な臨床症状を示し, そ

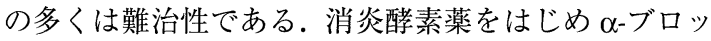
カーや抗菌薬, 精神安定薬などの各種薬物治療, 前立 腺温熱治療, 前立腺マッサージなど様々な治療法が試 みられているが必ずしも十分な効果を得られていない のが現状である，慢性前立腺炎の病因として，排尿機 能障害, 前立腺腺管への逆流, 通常では検出されない 微生物, 自己免疫の関与, 化学物質, 交感神経反射の 異常などが考えられているが(17)18)いまだに十分解明さ れたとは言い難い。また，同時に複数の病因の関与も 予測され，難治性の理由の一つと考えられる．植物工 キス製剤であるセルニルトン ${ }^{\circledR} は$ 慢性前立腺炎に適応 のある数少ない薬物の一つである. 1960 年 AskUpmarkにより初めて慢性前立腺炎に使用され ${ }^{19)}$ ，そ の後, セルニルトン ${ }^{\circledR}$ 臨床効果についてはいくつかの 検討がなされており, その有効率は 75 ～ $88 \%$ と報告さ れている ${ }^{20)}$-23) . 今回我々は, 慢性非細菌性前立腺炎症 例 (IIIA 型：16 例, IIIB 型：8 例) に対するセルニル トン ${ }^{\circledR}$ )有效性について, NIH-CPSI・日本語版(岡山大 学案)を用いて再評価した. その結果, セルニルトン® 投与開始後 4〜6 週目の評価では, NIH-CPSI の各領域 の合計スコアは投与開始前に比べ有意に低下してお り, セルニルトン®の有効性が確認された。特に, 痛み
・不快感に関するスコアの低下は顕著であった。 それ に伴いQOL スコアも有意に低下していた. 項目 9 の 満足度に関する質問では, やや不満, 不満, 全く我慢 できないとした患者は投与前後で $91.7 \%$ から $33.3 \%$ に減少し, 半数の患者が投与開始後にほほ満足, 満足, 非常に満足と答えており, セルニルトン®の投与により 高い満足度が得られていた。各領域のスコアの合計が 投与前の $50 \%$ 以下に低下した症例ないしは項目 9 の 満足度が投与前より 2 段階以下に低下した症例を有効 症例とすると, 今回の検討における有効率は $66.7 \%$ で あった。

今回, セルニルトン ${ }^{\circledR}$ 臨床効果を投与開始後 4 〜 6 週目の比較的短期の成績で評価したが，慢性前立腺炎 の多くは長期の臨床経過をとり, 再発, 再燃を繰り返 す症例が少なくない.セルニルトン®投与期間中ならび に投与終了後の症状の推移を長期的かつ客観的に解析 することが重要であり，そのことからも NIH-CPSI の 有用性は高いと考えられる。こうした解析を基に適切 な治療（薬剂投与）期間を設定することが今後の課題 の一つと考える.また，セルニルトンの効果を最終的 に確認するためには prospective な比較試験が必要不 可欠であり，国際的な多施設共同臨床試験の実施が望 まれる。

\section{結 語}

1) NIH-CPSI の日本語版（岡山大学案）を作成し, その有用性を検討した。同案は，慢性前立腺炎の臨床 症状および QOLを的確に反映しており，有用であっ た.今後さらに，翻訳の質，妥当性および信頼性など 検討するに值する症状スコアと考えられた。

2) NIH-CPSI ・ 日本語版 (岡山大学案) を用いてセル ニルトン ${ }^{\circledR}$ 臨床効果を検討し，セルニルトンの慢性 前立腺炎に対する有効性が確認された。

\section{文 献}

1) Drach, G.W., Fair, W.R., Meares, E.M., Stamey, T. A. : Classification of benign diseases associated with prostatic pain : prostatitis or prostatodynia?. J. Urol., 120, 266, 1978.

2) Executive summary : NIH workshop on chronic prostatitis. Bethesda, Maryland, 1995.

3) Litwin, M.S., McNaughton-Collins, M., Fowler, F.J. Jr, Nickel, J.C., Calhoun E.A., Pontari, M.A., Alexander, R.B., Farrar, J.T., O' Leary, MP. J. : The National Institutes of Health chronic prostatitis symptom index : development and validation of a new outcome measure. Chronic Prostatitis Col- 
laborative Research Network. J. Urol., 162, 369375, 1999.

4) Shoskes, D.A., Zeitlin, S.I., Shahed A., Rajfer, J. : Quercetin in men with category III chronic prostatitis : a preliminary prospective, double-blind, placebo-controlled trial. Urology, 54, 960-963, 1999.

5) Nickel, J.C., Johnston B., Downey J., Barkin J., Pommerville, P., Gregoire, M., Ramsey, E. : Pentosan polysulfate therapy for chronic nonbacterial prostatitis (chronic pelvic pain syndrome category IIIA) : a prospective multicenter clinical trial. Urology, 56, 413-417, 2000.

6) Nickel, J.C., Downey, J., Hunter, D., Clark, J. : Prevalence of prostatitis-like symptoms in a population based study using the National Institutes of Health chronic prostatitis symptom index. J. Urol., 165, 842-845, 2001.

7) Ku, J.H., Kim, M.E., Lee, N.K., Park, Y.H. : The prevalence of chronic prostatitis-like symptoms in young men : a community-based survey. Urol. Res., 29, 108-112, 2001.

8) Nickel, J.C., Downey, J., Johnston, B., Clark J., Group, T.C. : The Canadian Prostatitis Research Group. : Predictors of patient response to antibiotic therapy for the chronic prostatitis/chronic pelvic pain syndrome : a prospective multicenter clinical trial. J. Urol., 165, 1539-1544, 2001.

9）前立腺炎：尿路感染症臨床試験ガイドライン第一 版, 日本泌尿器科学会尿路感染症臨床試験ガイド ライン作成委員会編, 第 1 版, 35-40, 金原出版, 東京, 1998 .

10) Wenninger, K., Heiman, J.R., Rothman, I., Berghuis, J.P., Berger, R.E. : Sickness impact of chronic nonbacterial prostatitis and its correlates. J. Urol., 155, 965-968, 1996.

11) Bullinger, M., Alonso, J., Apolone, G., Leplege, A., Sullivan, M., Wood-Dauphinee, S., Gandek, B.. Wagner, A,Aaronson, N., Bech, P., Fukuhara, S., Kaasa, S., Ware, J.E. Jr. : Translating health status questionnaires and evaluating their quality : the IQOLA Project approach. International Quality of Life Assessment. J. Clin. Epidemiol.. 51, 913-923, 1998.

12) Fukuhara, S., Bito, S., Green, J., Hsiao, A., Kurokawa, K. : Translation, adaptation, and validation of the SF-36 Health Survey for use in Japan. J. Clin. Epidemiol., 51, 1037-1044, 1998.

13) Fukuhara, S., Ware, J.E. Jr., Kosinski, M., Wada, S., Gandek, B. : Psychometric and clinical tests of validity of the Japanese SF-36 Health Survey. J. Clin. Epidemiol., 51, 1045-1053, 1998.

14) Kunishima, Y., Matsukawa, M., Shimizu, T., Tkahashi, S., Hotta, H., Hisataki, T., Itoh, N., Tsukamoto, T., Hirose, T., Mori M. : The usefulness of the National Institute of Health Chronic Prostatitis Symptom Index in Japan. J. Urol., 165 suppl.. 24-25a, 2001.

15）白井將文, 石井延久, 高波真佐治, 長尾光一, 鈴木 実, 大石雅彦, 井 洋一, 細江洋純：国際勃起機能 スコア (International Index of Erectile Function) の日本における妥当性の検討. IMPOTENCE, 14, 1 - $28,1999$.

16）木本康介, 岩坪映二, 小谷俊一, 牛山武久：勃起機 能問診票について. 日本性機能学会雑誌，16,153, 2001.

17) Nickel, J.C. : Prostatitis : evolving management strategies. Urol. Clin. North Am., 26, 737-751, 1999.

18）公文裕巳：前立腺炎. 泌尿器科診断と治療の最前 線, 初版, 168-175, 先端医療技術研究所, 東京, 2000.

19) Ask-Upmark, E. : On a new treatment of prostatitis. Glana. Pal., 2, 115, 1960.

20）城代明仁，丸田直樹，下前英司，櫻木 勉，進藤和 彦，斉藤 泰：慢性前立腺炎に対するセルニルト ンの長期使用経験。泌尿器科紀要, 34, 561一 568 , 1988.

21）鈴木孝憲，黒川公平，真下 透，竹沢 豊，小林大 志朗, 川島清隆, 戸塚芳宏, 塩野昭彦, 今井強一, 山中英寿：慢性前立腺炎に対するセルニルトンの 臨床効果. 泌尿器科紀要, 38, 489-494, 1992.

22) Buck, A.C., Rees, R.W., Ebeling L. : Treatment of chronic prostatitis and prostatodynia with pollen extract. Br. J. Urol., 64, 496-499, 1989.

23) Rugendorff, E.W., Weidner W., Ebeling, L., Buck, A.C. : Results of treatment with pollen extract (Cernilton N) in chronic prostatitis and prostatodynia. Br. J. Urol., 71, 433-438, 1993.

(2001 年 6 月 29 日受付, 12 月 4 日受理)

\section{日本泌尿器科学会学術委員長コメント}

Response criteria としての symptom score や健康 関連 QOL（HQOL）は, 近年臨床の現場や種々の臨床
疫学研究において盛んに活用されるようになってき た. 代表的な健康関連 QOL 尺度の一つである MOS Short-form 36-Item Health Survey (SF-36) は, IQOLA 
(International Quality of Life Assesment) によって, 現在 25 力国以上の言語に翻訳され，検討されている. 欧米文化のもとで開発された symptom score や QOL 尺度の内容が, 言語的に, また文化的に日本人に理解 しうるものか，あるいは価值観に適合するものである か, これらの問題を解決するためには, 多段階にわた る翻訳, 逆翻訳, 翻訳の質的検討, さらに信頼性と妥 当性の検討が必要である。このような検討を経た日本 語版 SF-36 11 $^{\prime}$ 様々な疾病に臨床応用されている。 た，同様に泌尿器系悪性腫瘍に特異的な QOL 評価と しては, 膀胱癌の FACT-BI, 前立腺 FACT-P がこのよ うな検討をへて確立されている ${ }^{2}$. 国際前立腺症状ス コア (I-PSS) についても, 日本泌尿器科学会の ad hoc committee による翻訳の後に, 現在 validation study が進行中である．今回岡山大学案として紹介された NIH-CPSI については，同様なステップを踏んで正式
の日本語版が作成され, 真に臨床に有意義な症状スコ アとして今後定着・活用されることが期待される.

赤座 英之

日本泌尿器科学会学術委員長

\section{文献}

1) Fukuhara, S., Bito, S., Green, J., Hsiao, A., Kurokawa, K. : Translation, adaptation, and validation of the SF-36 Health Survey for use in Japan. J. Clin. Epidemiol. (1998; $51: 1037-1044$.

2) 膀胱癌前立腺癌患者用 QOL 調查票 FACT (Functional Assessment of Cancer Therapy）の日本語 版開発における pilot study 桶之津淳子, 新美三 由紀, 赤座英之, 宮永直人, 武島 仁, Erementco, S., Cella, D.F., 癌と化学療法 26:657-26 : 657-666, 1999. 